\title{
A Qualitative Case Study of an Exemplary Science Teacher's Earth Systems Education Experiences
}

\author{
Hyonyong Lee* \\ Department of Earth Science Education, Kyungpook National University, Daegu 702-701, Korea
}

\begin{abstract}
The purposes of this case study were (1) to explore one experienced teacher's views on Earth Systems Education and (2) to describe and document the characteristics of the Earth Systems Education (ESE) curriculum provided by an exemplary middle school science teacher, Dr. J. All the essential pieces of evidence were collected from observations, interviews with the experienced teacher and his eighth grade students, informal conversations, document analysis, and field notes. The NUD*IST for MS Windows was used for an initial data reduction process and to narrow down the focus of an analysis. All transcriptions and written documents were reviewed carefully and repeatedly to find rich evidence through inductive and content analysis. The findings revealed that ESE provided a conceptual focus and theme for organizing his school curriculum. The curriculum offered opportunities for students to learn relevant local topics and to connect the classroom learning to the real world. The curriculum also played an important role in developing students' value and appreciation of Earth systems and concern for the local environment. His instructional strategies were very compatible with recommendations from a constructivist theory. His major teaching methodology and strategies were hands-on learning, authentic activities-based learning, cooperative learning, project-based learning (e.g., mini-projects), and science field trips. With respect to his views about benefits and difficulties associated with ESE, the most important benefit was that the curriculum provided authentic-based, hands-on activities and made connections between students and everyday life experiences. In addition, he believed that it was not difficult to teach using ESE. However, the lack of time devoted to field trips and a lack of suitable resource materials were obstacles to the implementation of the curriculum. Implications for science education and future research are suggested.
\end{abstract}

Keywords: case study, exemplary science teacher, earth systems, integrated science

\section{Introduction}

Since the early 1990s, a consensus has emerged about the need to improve K-12 science education, particularly in earth and space science education. The American national organizations and professional communities of earth science (e.g., AAAS, NASA, NSTA, etc) agreed that the earth system approach is a critical element to restructure school science education in the U.S. (Lee et al., 2004; Lee and Fortner, 2005). For example, the National Science Education Standards began to express the importance of the ideas of systems for earth and space science education and integrated science education (NRC, 1996). The Biological Science Curriculum Study (BSCS) found

\footnotetext{
*Corresponding author: hlee@knu.ac.kr

Tel: 82-53-950-5917

Fax: 82-53-950-5946
}

that 31 states of the U.S. have offered integrated science and that "Earth systems" was used as a major theme of integrated science education in many states (BSCS, 2000). The presence of earth systems in science education is an important phenomenon because such education may increase the global science literacy of all students in their future of a new global era (Kim and Kwak, 2004; Lee et al., 2004; Mayer, 1995, 1997, 2002, 2003).

Earth Systems Education (ESE) has been identified as one of the exemplary integrated science programs using the Earth system as a unifying theme. ESE provides a framework of seven essential understandings about earth systems to guide restructuring and development of integrated science curriculum (Lee et al, 2004; Mayer, 2002, 2003; Mayer and Fortner, 1995; Shin, 2001). Since then, ESE has been implemented in different ways across the world. Several countries have been interested in ESE as a 
reform or restructure for earth science contents of science curriculum (Ben-zvi-Assaraf and Orion, 2005a, 2005b; Hlawatsch et al., 2003; Kali et al., 2003; Kim and Kwak, 2004; Lang, 2002; Shin et al., 2005; Park, 2001, 2006).

In Korea, since ESE was first presented to Korean science educators by Mayer (1996), the national science curricular have focused on the use of the earth systems as a cohesive theme for restructuring earth science contents (MEST, 2009; MOE, 2000). A number of researches have been conducted on the possibility of ESE's school application in Korean school with its own contexts and teaching materials for secondary students (Cho and Kang, 2002; Cho et al., 2006; Kim and Jeong, 2009; Kim et al., 2009; Lee and Kim, 2009; Lee and Kwon, 2008 ; Lee et al., 2007; Lim et al., 2000; Oh et al., 2009; Oh and Kim, 2010; Yu et al., 2007, 2008). For example, Cho and Kang (2002) found that ESE activity helped students understand earth systems, subsystems of the Earth, and interactions between the earth systems. ESE instructional strategies had positive effects on students' academic achievement and attitude toward science. Kim and Jeong (2009) proposed that educators' understanding of earth systems was very important, and ESE could be a compulsory component of the national school curriculum. In addition, Lee et al. (2007) reported that exemplary aspects of various integration should be provided to science teachers to enhance their Global Science Literacy (GSL). The institutionalized approaches to developing ESE curriculum could help science teachers activate ESE teaching in their classroom.

Despite these research efforts to implement and disseminate ESE to the schools, there have been little empirical studies of the implementation of ESE in real classroom contexts. In particular, there is no research that investigates the exemplary ESE program as it is implemented in practice or the exemplary science teachers' ESE experiences. How does the exemplary science teacher's views on ESE experiences? What does the implementation of ESE teaching and learning look like? Moreover, what are the major characteristics of the exemplary ESE curriculum and instruction? This qualitative study is expected to provide empirical evidence related to these questions. This study is designed to inform the exemplary science teacher by providing descriptive and analytical accounts on ESE teaching and learning as an innovative integrated science curriculum, and by providing insight into barriers, benefits and obstacles as well as ESE instructional strategies and characteristics of the curriculum. The specific questions to be addressed in this study are:

1. What are the characteristics of ESE curriculum and instruction developed by the exemplary science teacher?

2. What are the exemplary science teacher's views on ESE, the framework of ESE, and other components of ESE curriculum and instruction?

3. What does the teacher perceive to be some of the benefits, barriers, or difficulties with teaching ESE?

\section{Research Methods}

This study is primarily focusing on one middle school science teacher's ESE teaching and learning experiences in a natural context. The purposive sampling was used in this case study because "the logic and power of purposeful sampling lies in selecting information-rich cases for study in-depth. Information-rich cases are those from which one can learn a great deal about issues of central importance to the purpose of the research" (Patton, 1990, p. 169). One exemplary science teacher and his science classroom in a middle school was an information-rich site for this case study.

Teacher: This study primarily focuses on one eighth grader teacher, Dr. J(male)., who developed the ESE curriculum in his school and utilized ESE-based curriculum and instruction. He is not only a wellknown person to educators in ESE, but also an enthusiastic teacher. He has more than 20 years of teaching experience in middle school. After completing 
his master's degree in science education, he finished his Ph.D. in the same area in 1995. In his doctoral dissertation, he conducted a case study that examined the nature of, and the processes involved in, the initiation and implementation of an innovative twoyear science curriculum [Earth systems curriculum] for ninth and tenth grades, in a suburban school district. The ESE-based science curriculum at the high school in that same district replaced more traditional Earth science and biology courses at the $9^{\text {th }}$ - and $10^{\text {th }}$-grade levels. His study focused on the teachers involved in the change process and the influence that other stakeholders (e.g., teachers, administrators, parents), as well as external factors (e.g., local university educators, external funding sources, etc.), had on the process.

Dr. J.'s major interests focus on ESE as an innovative integrated science curriculum, and the Earth system approach to curriculum integration. He is very familiar with the seven understandings of the ESE framework and principles of ESE-based teaching and learning. He has implemented an ESE curriculum for $7^{\text {th }}$ and $8^{\text {th }}$ grades in his middle school since 1992 and has incorporated ideas and principles of ESE into his instruction. He and the other science teachers at the middle school have developed a new science curriculum that focuses on an Earth system approach.

Research site: The primary research locations were Dr. J.'s science classroom in the middle school and field trip locations. The middle school selected for this study is located in an upper-middle class community in the eastern area of a large city in Ohio, the U.S. This B. City School District was recognized as one of the highest performing school districts in Ohio. The performance on proficiency tests by students enrolled in this school district was higher than the state average. Students attending the Lincoln High School in the same school district are predominantly college bound - more than $90 \%$ of the high school students attend colleges and universities. This research had conducted from January to June, 2001 at the middle school. Permission to access the teacher and students was obtained from Mr. W., Principal, prior to this study. The formal approval to do this study from the Human Subjects Review Board at The Ohio State University was received and written consents were also obtained from all students agreeing to participate in this study and their parent or guardian

\section{Data Analysis Procedure}

For purposes of triangulation, evidence was collected from several major data sources: semi-structured interviews with Dr. J., classroom observations, selfreported data from the teacher, and documents including the curriculum framework, instructional resources and materials, and teacher's handouts. Before analyzing the data collected in this study, videotapes and audiotapes from class observations and interviews were selectively transcribed. In order to manage the data, transcripts were organized and categorized according to date, source type, and so on. The following major data sources were analyzed: interviews, documents, field notes, and artifacts. Using inductive analysis (Patton, 1990), I reviewed interview transcripts, classroom observations, documents, and field notes carefully and repeatedly, and then, I tried to look for key ideas, events, or activities in the data. When I worked with my initial data, I used one function, "free node" in the NUD*IST for MS Windows. This initial data reduction process was very helpful in narrowing the focus of an analysis in order to draw accurate conclusions (Miles and Huberman, 1994; Patton, 1990; Corbin and Strauss, 2008).

To answer the research question 1, I first read all transcriptions and written documents repeatedly and I tried to find rich evidence through "content analysis" of documents (focusing on students' notebooks), interviews, and observations (Merriam, 1998, 2009). The evidence for research questions 2 and 3 are based upon interviews with Dr. J., his responses to the written questions, classroom and field trip observations, analysis of documents, and my field notes from the observations. Actual words of Dr. J. and direct quotations from his responses to the written questions were primarily used to describe the teacher's views on 
ESE experiences. To report characteristics of ESE curriculum provided by the teacher, I primarily examined documents and curriculum and instructional materials which closely correspond to the research questions.

The two major techniques were used for establishing the degree of transferability and credibility in this qualitative case study. First, combining different kinds of data sources and methods provided cross-data validity checks (Patton, 1990) and reduced possible errors and biases that come from one particular method. Second, I used member check technique both during the investigation and at its conclusion. I discussed my interview and observation transcripts with the teacher in order to make changes or corrections when necessary. Further, my conclusions, and interpretations were checked with the teacher prior to drawing my conclusions.

\section{Research Findings}

\section{Characteristics of ESE Curriculum and Instruction}

I realized that the ESE curriculum included several unique characteristics compared to other curricula. Therefore, I made a list of features of the ESE curriculum and instruction, and tried to create more opportunities to discuss the features with the teacher.

\section{Units and Topics of the Curriculum}

Earth Systems Education curriculum was a grassroots effort of Dr. J and other science teachers in the middle school. Both the seventh and eighth grade integrated science curricular were based on the Framework of the Seven Earth Systems Understandings and Earth system approach (Table 1). The framework provided a basis for Earth systems teaching and for use in infusing Earth systems concepts into Dr. J.'s curriculum (Jax, 1995; Lee et al., 2004; Mayer, 1991; Mayer and Fortner, 1995).

Dr. J. gave a brief history and listed the characteristics of all units and topics in his seventh grade and eighth grade curricula. The following question was asked in the interview:

Researcher: Could you tell me how you determined the units and topics in your seventh and eighth curriculum in your school?

Dr. J.: We chose the topics for our curriculum by using the ESE framework, trying to have all of the sciences represented, although most of what we do fits mainly into Earth science and life science, and wanting to have a local focus in the seventh grade, and to start the eighth grade with a local focus and go to a more global focus. We have made adjustments to our curriculum over the years and are getting ready to propose and discuss changes to it. We are doing this on our own volition and not as a result of a district directive. We have a lot of ownership of our curriculum (Interview).

Dr. J.: Our curriculum was planned entirely by the three science teachers who were here 11 years ago. Two of us are still here. We were assisted in the process by being able to work with colleagues from other central Ohio school districts through an Eisenhower-funded grant. The grant also allowed us to explore a variety of curriculum materials and teaching strategies from which we chose what we do. The school district allowed us to make all of the decisions. (Written Question).

Table 1. Framework for Earth Systems Education (Mayer, 1991)

Framework of the Seven Earth Systems Understandings

Understanding \#1: Earth is unique, a planet of rare beauty and great value.

Understanding \#2: Human activities, collective and individual, conscious and inadvertent, affect planet Earth.

Understanding \#3: The development of scientific thinking and technology increases our ability to understand and utilize Earth and space.

Understanding \#4: The Earth system is composed of interacting subsystems of water, rock, ice, air, and life.

Understanding \#5: Planet Earth is more than 4 billion years old and its subsystems are continually evolving.

Understanding \#6: Earth is a small subsystem of a solar system within the vast and ancient universe.

Understanding \#7: There are many people with careers that involve study of Earth's origin, processes, and evolution. 
In addition, he explained the major characteristics of his units and topics.

Dr. J.: Seventh graders study ecosystems, populations, solid waste issues (related to human population) and the use of natural resources. Eighth graders study drainage systems, wetlands, biodiversity, weather, climate and climate change, plate tectonics, evolution and Ohio natural resources. These topics all heavily involve the subsystems of air, water and life and occasionally ice and land.

As shown in Table 2, the topics and units strongly supported what Dr. J. explained to me. ESE-based science topics and units are richly based on student's real world experiences, local environments, classical and emergent environmental problems and scientific phenomena (e.g., biodiversity of the city of Lincoln, Ohio's population, cycles in nature, drinking water for Franklin County, global warming, weather). Dr. J. is teaching a variety of locally- and globally-relevant scientific and environmental topics.

The focus of the seventh grade science was to begin locally and extend regionally, so students learned about what was going on in their own backyards and then extended their learning to local and state environmental issues (e.g., the Great Lakes). In the eighth grade curriculum, the focus began with local watersheds then extended to a global perspective. Global environmental issues included El Niño, global warming, ozone hole, etc. The curriculum was also designed for students to use aspects of biology, geology, and physical sciences to study their environment and their place in it, and to explore how the Earth systems have changed over time.

As I worked with my observation data repeatedly, I was able to identify the teacher's consistent instructional pattern and teaching sequence. He has a relatively simple pattern to teach most of the units.

Table 2. Major science units and topics in the seventh and eighth grade

\begin{tabular}{|c|c|c|}
\hline & Seventh Grade & Eighth Grade \\
\hline $\begin{array}{l}\text { Major } \\
\text { science } \\
\text { units } \\
\text { and } \\
\text { topics }\end{array}$ & $\begin{array}{l}\text { - Mapping/Leaves } \\
\text { - Ecosystems } \\
\text { - Cycles in Nature } \\
\text { - Rock Cycle } \\
\text { - Nitrogen Cycle } \\
\text { - Carbon Cycle } \\
\text { - Water Cycle } \\
\text { - Microscope } \\
\text { - Natural Resources } \\
\text { - Nuclear Energy } \\
\text { - Biomass } \\
\text { - Petroleum } \\
\text { - Natural Gas } \\
\text { - Propane } \\
\text { - Ohio's High Sulfur Coal } \\
\text { - Population } \\
\text { - U.S. Population } \\
\text { - Ohio Population } \\
\text { - Solid Waste }\end{array}$ & $\begin{array}{l}\text { - Drainage Systems } \\
\text { - Artificial-Storm Sewers, Sanitary Sewers, Urban Watershed. } \\
\text { - Natural-Streams, Watersheds, Contour Maps. } \\
\text { - Human Influence } \\
\text { - Wetlands } \\
\text { - Estuaries, Pickerington Ponds, Food Webs } \\
\text { - Geology, Water Testing } \\
\text { - Human Influence } \\
\text { - Groundwater } \\
\text { - Water Movement, Human Influence } \\
\text { - Biodiversity } \\
\text { - Genetics, Species } \\
\text { - Effect of Humans on Biodiversity } \\
\text { - Weather } \\
\text { - Global: Earth Motions, Sun, Rotation of Earth, Solar Energy, Winds, Air Pressure. } \\
\text { - Local: Air Masses, Fronts, Maps. } \\
\text { - Change Through Time } \\
\text { - Climate Change, Acid Rain } \\
\text { - El Nino, Ozone Depletion } \\
\text { - Volcanic eruptions, Plate tectonics } \\
\text { - Evolution, Fossil Evidence, Extinctions } \\
\text { - Ohio's Natural Resources } \\
\text { - Ohio's Geology } \\
\text { - Natural Resources }\end{array}$ \\
\hline $\begin{array}{l}\text { Fiel } \\
\text { trips }\end{array}$ & $\begin{array}{l}\text { - Blacklick Metro Park } \\
\text { (one day field trip) } \\
\text { - Trash tour of the county } \\
\text { landfill } \\
\text { - Tar Hollow State Park } \\
\text { (three days field trips) }\end{array}$ & $\begin{array}{l}\text { - Battelle-Darby Metro Park (one day field trip) } \\
\text { - Pickerington Ponds Metro Park (one day field trip) }\end{array}$ \\
\hline
\end{tabular}


First, he introduces new topics, and then shows videos, and finally has some demonstrations, or interesting things to motivate his students. Sometimes, he begins with asking the students some questions, doing brainstorming, or having students construct concept maps in order to identify their pre-existing knowledge and beliefs. Second, he explains activity instructions and introduces materials, references, and other detailed information related to the activity. Third, he lets students do the activities (usually group activities) and helps students do it well. He promotes a very interactive atmosphere, so students actively participate in generating new ideas and questions. While he is observing students' activities, he is also evaluating students' individual contributions to the group. Finally, students usually take open-ended quizzes, present their projects, or provide their portfolios. He evaluates students' grades by using rubrics he designed, quizzes, and concept maps he made.

\section{Syllabus}

After I reviewed and analyzed the teacher's syllabus of Earth Systems Science for eighth grade, my first finding was that all objectives in the units of syllabus fit well into the major features and themes of Earth Systems Education. For instance, one distinct characteristic in ESE is a locally relevant curriculum that meets the broad needs of students. In the syllabus, most science content within ESE was highly related to local science topics and environmental issues. In ESE, students were allowed to connect and apply their learning to their environment and local living place. According to the syllabus, each unit focused on Earth Systems Science and included local environmental issues and science topics (e.g., the biodiversity of our local community, Ohio wetlands, the quality of drinking water for Franklin County, Ohio).

\section{Field Trips for Seventh Graders}

According to the science curriculum, there are three field trips for seventh graders and two field trips for eighth graders. The first trip for seventh graders is to
Blacklick Metro Park. The major purpose is to study three main ecological areas: Forest, stream, and pond. Surveys of organisms; water quality; biological, chemical, and physical characteristics of a stream; and the geology of the area are examined. The second trip is a trash tour of the county landfill, a wastewater treatment facility, and a compost plant. Students get a first-hand look at how humans deal with solid and liquid wastes. The third trip is a three-day outdoor education camp at Tar Hollow State Park. Dr. J. said that this trip has been done for 47 years. During this study, I did not have a chance to join the first and second field trips for seventh graders because Dr. J. was only teaching eighth grade students. However, I had an opportunity to observe the third field trip because Dr. J. helped other teachers for the two night camping programs at the state park. Even though I observed this nature study camp for only one day, I realized that this trip provided students with a very good opportunity to learn and appreciate nature and the need to conserve it.

There are several notable features I noticed. First, students benefited from a very interesting bus field trip along the way. While they were on their way to the park, the school bus stopped at 30 different places to take a rest and to look at specific features more closely. As students traveled along, each listed feature was pointed out by name and number. In most cases, students had at least one question or statement to read and respond to for each feature. According to the bus trip guide, the major content in the bus trip focused on the roadside evidence of glaciers in Ohio, rocks, geologic features and structure, landfill, and plants.

The second feature of the camp trip is that students had the opportunity to get close to nature. They slept in cabins in the woods, they hiked along trails with flowers and budding trees, and they enjoyed fishing at a pond. They had the chance to smell, see, touch, and hear all of the things around them.

The third feature of the camp trip is the array of planned projects and activities. Each morning and afternoon, interesting activities were planned for the students. For instance, during the first day project 
(which they called combined Bus/Lake and Stream activities), students compared and contrasted the meadow environment with the forest environment. Students walked down the middle of a stream to the lake and looked for interesting animal and plant life. The teachers provided the following 13 different types of science activities on the first day: (a) The Rise and Fall of the Ohio Canals, (b) Traveling the Ohio-Erie Canal, (c) Glaciers in Ohio, (d) The Logan Elm, (e) Be a City Planner, (f) Adapting to an Environment, (g) Collect and Observe Amphibian Eggs, (h) Collect and Observe a Salamander or Crayfish, (i) Rocks at Tar Hollow, (j) Collect and Observe Three Water Insects, (k) Can You Ride a Water Cycle?, (l) Whatever the Weather, and (m) Check Out the Stream. Before students started these activities, they hiked in the stream bed, observed the plant and animal life dependent on the water environment, and saw how water is carving away the land. The hike ended at the human-made lake, Pine Lake, for recreation and water control. At the end of the hike, students could select several activities and follow the instructions on the related guides.

\section{Field Trips for Eighth Graders}

Eighth graders also go on two field trips. The first trip is to Pickerington Ponds Metro Park, a glaciallyformed wetland that has been significantly modified by humans and continues to be threatened by development. Students study the biology and chemistry of the pond, a succession area, and how both are impacted by the geology. The second trip is a service learning trip to clean up a stream and monitor the water quality of the stream. The site, Battelle-Darby Metro Park, is in the city. A part of the trip is a discussion of human impact on the site and how human awareness of the plants and animals that live there can be heightened. During my observation period, I joined the second field trip to the BattelleDarby Metro Park.

Before the trip, students were divided into three groups because they were supposed to work with three topics at three different areas: Area A: Stream
Life and Water Quality, Area B: Stream Characteristics, and Area C: Nature Trail Walkabout. First, students collected water insects from the stream to use with the Stream Quality Assessment Form. In Area A there were two major activities to assess water quality. Second, students were assigned several physical and chemical tests to perform on a sample of the stream water. They used the test kits and thermometers to collect the following data to assess water quality: $\mathrm{pH}$, dissolved oxygen, nitrates, phosphates, hardness, water temperature, and air temperature. Activities around Area B included three parts: Part I. Rock identification, Part II. Mapping the stream bed, and Part III. Calculating the velocity of the stream. During students' visit to Area B, they identified the different types of rocks that were found in the stream bed. They also were asked to figure out where the rocks originated and to make a profile of the stream based on the measure of the depth and the width of the stream.

In addition, students calculated the area of the stream in profile and stream velocity. They were eager to learn and were actively involved in what was happening. In the final Area $\mathrm{C}$, students looked for the organisms living along the nature trail and surrounding the wetlands, and recorded the ones that they found. In addition, they took small soil samples from the succession area near the trail for chemical analysis upon returning to school.

\section{Mini-Projects}

Each student developed two oral presentations about any science topics that interested them. Dr. J. told me that the students are not allowed to present on any topics they had covered in class or would cover the rest of this school year. When I asked him about any repetition of topics, he responded that,

Some reservations we have about these projects are the repetition and recycling of topics over the years and the roles parents sometimes play in the projects. As we review our curriculum later this year we will decide how we will change/improve the way we have students do these projects. 
In his syllabus, Dr. J. provided detailed information about the mini-projects and oral presentations as follows:

\section{STUDENT PROJECTS}

Students will develop an oral presentation (mini-project) on a science topic of their choice in each of the first and fourth grading periods. The presentation will be videotaped outside of school, or at school in front of the class or to Dr. J. Each presentation will last four to five minutes and will be supported by a variety of visuals that could include poster(s), Astound-based material, and/ or actual objects. Specifications of the expectations for mini-projects will be given to students. These projects will be due at a time scheduled by each student and all will be completed by one week before the end of the grading period (first and fourth) in which it is assigned. If a student does not complete a project on time, parents will be notified immediately.

During the second and first part of the third grading periods, students will develop and present either an invention project or a science fair project. These will be presented by all eighth grade students at the Invention Fair that is scheduled this year on Thursday, March 0 ,
0000. Class presentations of these projects will take place that same week starting on Monday, March 0 , 0000 .

He also expressed some benefits from the miniprojects.

The mini-projects allow students an opportunity to pursue information about a topic they are interested in. They also have students plan how to share the information they have collected. The invention or science fair project allows students to express their creativity in terms of the scientific method or in developing or improving upon an invention. (Written Question)

In order to assess the mini-projects, he used a simple evaluation form and provided comments or suggestions about students' oral presentations (Table 3 ). It seems that the mini-projects gave students good opportunities to explore science topics, to gather information, and to share it in an oral presentation by using visuals. The teacher also provided productive and useful feedback and comments to the students through the evaluation form.

Table 3. Oral presentation evaluation form

Science Grade 8 Oral Presentation Evaluation - 150 points

Dr. J. (Comments/Suggestions on back)

Name Per

1. Appropriate amount of material presented. out of $25 \mathrm{pts}$.

2. Accuracy of the material presented. out of 25 pts. (includes knowledge of material)

3. Material well organized. out of 25 pts.

4. Appropriate visual aid and explanation of it.

5. Good use of "reminders" like note cards. out of 30 pts.

6. Make eye contact with "audience". out of 30 pts. out of 15 pts.

Date Audience

Total points out of 150 . Topic

(back side)

Comments/Suggestions

The comments that have been "checked" relate to your presentation. Don't read your notes so much -use them more as a "quick reference."

You need a greater variety of things on your visual(s). Refer to your visual(s) more often throughout your presentation. Things on your visual(s) are too small for your audience to see clearly. Good use of notes. Very nice visual(s). Good use of visual(s). 


\section{Instructional Materials}

I found that there was no official textbook in this science class. During this study, I felt that students seemed to enjoy science learning without textbooks. In my short written survey, I asked students to explain the major reasons why they enjoyed or disliked the current science class, if they liked or disliked science classes. Thirty-three students responded that they liked to learn science. In general, these students expressed positive attitudes about no textbook (all student names in this study were replaced to protect the identity of those involved in the study), as shown by their responses:

Jeffrey: I enjoy having the teacher I have because he teaches things in fun easy to learn things. I have always enjoyed science because of what it deals with. Not having a textbook makes things easier to expand upon. Science is really interesting.

Debra: I think the reason I like science is very interesting and we learn it in more of a hands on way instead of just reading it out of books, like we do in other classes.

Patricia: Dr. J. is a good teacher and our class is very flexible because we dont have textbooks, I feel we have more fun and learn more with this system.

James: I like learning science without a textbook because it helps you concentrate better. When you are learning from a textbook its really hard to remember what you learned because its so boring. But learning without a textbook we got more involved and have fun which makes us remember and learn.

Robert: I like not using a textbook because it makes the class more interesting and fun. I also like doing experiments in class.

The other 4 students responded that they did not like to learn science, as shown by their responses:

Sharon: Difficult to understand, dont feel that I need to know what I am being taught.

Howard: Its doesnt usually click with me like other things the first time I hear it. I wish it were more fun, more trips. Im glad I will be in basic science next year because it will not be too hard. Its just too complex to understand.

Richard: Science doesnt interest me.

Derrick: I dont really have a main reason why I dont like it.

Students were given handouts which contained projects for them to work on, either individually or in groups. Students make their own textbook by using instructional materials provided by the teacher. In an interview with Dr. J., he explained,

Researcher: I think, they [students] made their own textbook.

Dr. J.: Yes, Thats how I approach it. Their notebook is their textbook. I have talked with students many times throughout the year. Especially, I told them at the beginning of the year to make sure they understand all the things we do. They are writing their textbook. They need to do a good job of that. And I do grade notebooks. I think kids handle (the way I have them do notebooks) that pretty well. Parents sometimes have a problem about that. But, I think kids handle it very well in terms of not having other books to carry all the time.

Researcher: I think your resources are very excellent compared to other textbooks. And, what instructional resources do you use for science class?

Dr. J.: And the GEMS materials [Great Explorations in Math and Science], SEPUP [Science Education for Public Understanding Program], ACES [Activities for the Changing Earth System]. Some of things are from EAGLS [Earth Systems-Education Activities for Great Lakes Schools] through a Sea Grant.

Because they have no official textbook, students' notebooks were considered valuable materials in this science class. I realized that the most significant material in the classroom was the student's own notebook that functioned as the textbook. In fact, the students were not permitted to remove pages from their notebook just as they would not tear pages out of a textbook. The students also liked to study science with the teacher's instructional materials rather than the textbook-based materials. 


\section{Interpretations}

Throughout the study, I found several noteworthy characteristics of ESE curriculum and instruction. The first is the array of units and topics in the curriculum; ESE focuses on locally-relevant topics at the beginning leading to a global perspective. As observed in Table 2, Dr. J. tried to focus on local examples of each topic, especially in the seventh grade and the beginning of eighth grade. The ESE curriculum also includes global level issues for eighth graders. In other words, the major content includes topics that address the most important issues of the day at the local, regional, and global levels. For instance, the students study such local issues as the changing Metro Parks and the human impact on them, how acid rain affects the place where they live, and how humans have altered the local watershed and environment. Other topics include global climate change, rainforest destruction, wetland destruction, and ozone depletion. Those units and topics reflect the major themes of the Seven Earth Systems Understandings, such as human influence and interacting subsystems.

With regard to the exemplary unit, students were very interested in learning about El Niño. In this unit, the students learned about the processes of El Nino, worldwide effects, human influence, scientists' research and efforts to predict this natural phenomenon. In an interview with Jeff, he addressed the reason he chose El Niño as his favorite unit:

\section{Researcher: Can you tell me why you like El Niño? \\ Jeff: Well I liked learning about it because it has to do with ocean stuff and thats kind of neat because you dont get to learn that much of it because theres no ocean around here and you got to learn how it worked and the different phenomenons that were in it that you didnt know about before.}

When Dr. J. taught this unit, he used several instructional methods, such as brainstorming, cooperative learning, and alternative assessment. It seemed that those methods were all based on ESE teaching strategies. In addition, he had consistent pattern and sequence to teach ESE. The second noteworthy characteristic of the ESE curriculum is the inclusion of field trips for both seventh and eighth grades. ESE has proposed the use of extensive fieldwork in the local community as one science teaching method that is consistent with establishing the climate of inquiry emphasized in the National Science Education Standards (Mayer and Tokuyama, 2002; NRC, 1996). Rudman (1994) explains that field trips can serve as tools for increasing the opportunities for students to improve their process and thinking skills and enhance interest in science learning. In addition, field trips also connect the school curriculum to the local environment and link cognitive and affective aspects of learning. Field trips provide an opportunity for observations, direct experience with nature and all materials, short investigations, and group discussions (Dori and Tal, 2000; Tal, 2001).

According to the evidence presented in the previous section, all activities in the field trips were designed for integrating the science disciplines or other subject areas (e.g., mathematics, language arts), and making curriculum connections between science and the real world environments. Dr. J. stated in the interview.

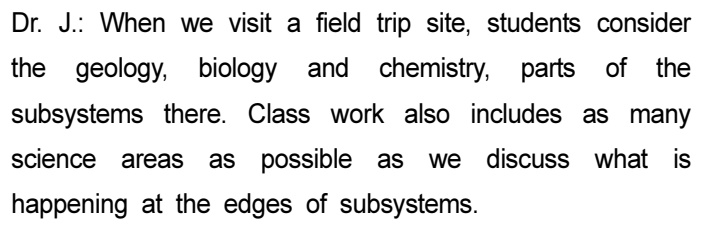

The field trips included excellent hands-on experiences for students. Students' responses indicated that they preferred to learn science through hands-on methods. While I observed two field trips, it was apparent that Dr. J. really enjoyed teaching science on the field trips.

A day in the field is better than the best day in the classroom. Students get to see what they are studying instead of trying to simulate it in some way. I get to teach in a way that makes the most sense - by doing things at the source. It is the ultimate hands-on experience. (Written Question)

The third noteworthy characteristic is the inclusion of mini-projects. According to Moje et al. (2001), 
"Project-based pedagogy engages children in textual and experimental inquiry about authentic questions... affords students and teachers opportunities to investigate, talk, read, and write about questions of interest to them" (pp. 469-470). Several reports and studies indicate that school projects have attempted to engage students in real world science learning experiences through inquiry-based projects based on interesting topics and questions (Goldman, 1997; Krajcik et al., 1998; Merino and Hammond, 1998; Moje et al., 2001).

Dr. J.'s mini-projects have been designed to provide students with extensive and authentic science learning experiences. From the beginning to end of the miniprojects, students gain experience with a variety of skills: information-searching skills (e.g., using the Internet); organizational techniques; communication skills; and presentation skills. The National Research Council (1996) recommends project-based learning and mini-projects as excellent ways to learn science. Finally, Dr. J. did not use a textbook. Throughout my observations, I realized that Dr. J. has tried to find good resources and activities, and then to use appropriate materials from many sources that include locally relevant or globally extended topics and content. Thus, he believed that students' notebooks could not be replaced by any formal textbook.

\section{The Teacher's Views on Earth Systems Education Experiences}

\section{Views on Earth Systems Education and the ESE Framework}

He explained that his integrated science curriculum was developed on the basis of Earth Systems Education and that ESE provided science educators with a conceptual approach to curriculum integration. Thus, major concepts and components of his school science curriculum were based on the Framework of the Seven Earth Systems Understandings. He stressed that the seventh grade curriculum emphasized more local topics and regional issues. In the eighth grade curriculum, the focus begins with local issues, then extends to a global perspective. He explained the structure and focus of the science curriculum.

Researcher: What are your general perceptions about ESE as an integrated science program or curriculum?

Dr. J.: ESE provides a framework for developing and using an integrated science curriculum that can have a local focus. This was the basis for the development of our science curriculum for grades 7 and 8 . Our seventh graders study local examples of ecosystems and the impact humans have had on them. Along the way they learn about ecosystem dynamics, cycles of matter and energy, the importance and chemistry of water quality, population, waste management and natural resources. Focusing on local ecosystems and environmental concerns give the science curriculum a relevance it did not have before. Eighth grade students begin their year studying local drainage systems, including wetlands, and how humans can have an impact on them. Then they move on to more global topics, including climate change, plate tectonics and evolution. We try to integrate plate tectonics and evolution as much as possible By focusing on topics of local and global importance, students study science in an integrated fashion. Aspects of all the sciences and even some social sciences are used to help students understand their local and global environment.

Next, when he was asked to explain the most important feature of ESE, he stressed the importance of providing local relevance in the curriculum as an important feature of ESE for students. His explanation:

I think the most important parts of ESE for teachers include the flexibility and control (hence ownership) that teachers have with the curriculum. For students, it provides a relevance lacking in many other programs because it can have a local focus. Students also are involved in a variety of learning strategies. ESE can be used anywhere by teachers wanting to use their locality as a part of the curriculum. ESE also provides an integrated approach to the study of Earth that reflects the way most people view the world around them. ESE can help students become informed and thoughtful citizens. 
With regard to his views on the Framework of the Seven Earth Systems Understandings (ESUs), he described that the seven understandings provide a wealth of opportunities for students to learn science. By looking at Earth as a set of interacting subsystems, students can realize that most of what is exciting and relevant in science is covered. It also includes the part that humans play in these interactions. By considering what humans do, students can become more informed citizens (based on Personal Communication). In addition, he said,

The seven understandings can be used as a framework to develop a curriculum that integrates not only the science disciplines, but also social science, humanities, and math. The local and global issues we study include what governments are doing about them. The curriculum can have a community advocacy component. Our eighth graders are involved in a variety of service learning opportunities throughout the year, a part of which includes environmental community service.

I also asked him about any influence of the Framework on his curriculum and instruction. He stated,

They [ESUs] have been the basis of the decisions we have made on the topics we have chosen to teach. By focusing on topics that include interactions among the subsystems of land, air, water, ice and life, including human life, students learn science as they experience it. Science is taught as it is experienced, as an integrated subject.

Regarding his views on the Earth system approach at the middle school, Dr. J. first described some major reasons that led him and his school to teach science using an Earth system approach. As he reflects in response to an interview question,

Researcher: Could you explain all reasons or factors that led you to teach science with an Earth system approach or integrated science approach?

Dr. J.: We used to teach life science in $7^{\text {th }}$ grade and earth science in $8^{\text {th }}$ grade. And, we became increasingly dissatisfied with the textbooks because of inaccuracies and also because there was little relevance for students.
We were supplementing those books anyway. We just decided that the textbooks werent appropriate for students. So, we adopted the Earth system approach. Some of us here (at school) have been involved in projects at The Ohio State University involving ESE, so we are quite familiar with the framework. We think now that what the student is doing is much more relevant, focusing especially in the $7^{\text {th }}$ grade on local things going on in central Ohio, and even things going on in their own backyard in some cases. In $8^{\text {th }}$ grade, we continue that for maybe the first half of the year, and then we get into more global issues like climate change, change over time, plate tectonics, something like that. So, it [the curriculum] is strongly environmental and again because we live in the city, and around the city there are a lot of environmental problems. And, its kind of a logical thing for us to focus on that. We are trying to make it relevant for the kids. And also, this is making the kids become good citizens, good participating citizens, too. So, that is an important part.

\section{Views on ESE-Based Teaching and Learning Strategies}

Dr. J. believed that ESE-based teaching and learning strategies work very well because they suit the learning styles of middle school students. With a focus on local places and issues, students are more engaged in what they study. He explained his major teaching strategies in response to the following question:

Written Question: What do you think about ESE-based teaching and learning strategies in your science class?

Dr. J.: We use a variety of teaching strategies, all of which are compatible with ESE. These include group work, a jigsaw approach, inquiry, labs, activities, field trips -full day, and period long "walkabouts," long term projects, videos, and Internet searches. I use concept mapping to either introduce an idea or to identify misconceptions or as a summary of what has been covered in a particular unit.

In addition, he described a long-term integrated project for the seventh graders.

Dr. J.: Our seventh graders complete a long-term integrated project that includes them selecting a topic that may be environmental in nature. It includes tasks 
that are part of all curriculum areas and also has an advocacy component. Students are expected to do research from printed materials and also do an interview. Social studies (maps and current events), math (data and graphs), language arts (edited paragraphs of information), and basic science concepts are all a part of the project. There also is an oral presentation.

Among those strategies, I asked him specifically about collaborative learning as I had observed that many classroom activities were designed for students to work as a group. According to Dr. J.,

Group work allows students to use their strengths to contribute to some group product. The social negotiation of students working out who does what provides them with some ownership of what they do. The sharing of work and the sharing of information among themselves makes the learning more meaningful. This works best in mixed groups of students. I generally use rubrics to assess each students individual contribution to the group and also the final product.

While observing his classes, I could easily see that constructivist ideas were embedded in Dr. J.'s teaching activities. For instance, he always expressed the importance of the students' preexisting knowledge and beliefs. He said, "It is important that students are aware of what they already know and that it could be incomplete or wrong." He called them "naïve notions," rather than misconceptions. He emphasized assessing students' naïve notions and used several teaching strategies to determine his students' prior knowledge and possible misconceptions. He stated,

Dr. J.: I have students assess these by group brainstorming and sharing and/or by the use of concept maps. This does not eliminate misconceptions but I think it identifies some of them. Constructivism also guides the learning process. Misconceptions often resemble early scientific hypotheses that have been disproved. By discussing these old ideas and showing how they were disproved helps students overcome their misconceptions. (Written Question)

As I started my observations and document analysis, I realized that the teacher had well-organized grading policies and assessment strategies. In his syllabus, he had very distinct and clear grading policies.

All assignments/tests/projects are assigned a certain number of points depending upon their difficulty and the length of time needed to complete them. Tests are typically 100 to 120 points, quizzes about half that, projects a little more than a test grade, the notebook is 50 points per grading period and typical homework assignments and class activities are 3 to 6 points each. Late work is acceptable up to a deadline and will receive reduced credit unless the student was absent. The grade for a student each grading period is approximately $40 \%$ tests and quizzes, $20 \%$ projects and $40 \%$ everything else. Grades are posted by student number about every two and half weeks. Students can always come in after school to check on grades. Generally, I do not accept extra credit. I want students to do their best on the "regular" credit. (Dr. J.s Syllabus)

As he described in his syllabus, he used a variety of methods to assess students' work (e.g., quizzes, openended questions, mini-projects, concept maps). While I observed his class, Dr. J. mentioned several times that using concept maps is one important tool to assess students' understanding. He explained that "it is a valuable tool for identifying misconceptions and for students to show how well they see the big picture. Students and I are in the process of developing a room-sized version of a concept map that represents the eighth grade curriculum. In addition, he explained in the interview that he has students do projects as another type of evaluation method.

Researcher: Do you have other types of evaluation methods?

Dr. J.: Yes, we have kids do projects. Part of the projects involve written components. I use a rubric for grading those. And, part of it is oral presentations, sometimes kids by themselves, sometimes by groups .... There are activities and some labs, and these papers can be graded. Thats part of assessment. Usually, when kids are working in groups, I try to assess each individuals contribution along with assessment of the group product. We try to do both. 


\section{Interpretations}

Dr. J. and other teachers in the middle school developed their ESE curriculum applying the conceptual framework and focus of ESE to curriculum integration. In the first interview, I realized that he has strong confidence and ownership as one of the developers of the ESE curriculum. He seemed to believe that he has been providing a really good opportunity for his students to learn about science within the context of the Earth systems. In addition, he appears to hold a positive attitude about his students' efforts and achievements.

\section{I think professionally we feel really good about what we are doing. Are we doing ESE as well as we can? No, I dont think so. We still have a ways to go. Of course, I think thats a sign about good teachers in general. Never really feel satisfied what theyre doing. Always, they want to improve. So, I think weve got a good start. (Written Question)}

As observed above, the framework of ESE was the basis of the decisions for the topics and units in the curriculum. ESE was incorporated into the middle school science curriculum. For example, the focus of the seventh grade science curriculum begins with local issues and topics in the students' local community and Ohio. The eighth graders delve further into both local and global issues, such as climate change, change over time, and El Nino.

From his point of view, the most important feature of their science curriculum was making science learning relevant to the students in their real world experience and real life environment. He believed that middle school students are constantly trying to make sense of the world around them. Therefore, he thought that the "science curriculum should have them consider their larger world (maybe just their community) and what is going on there is a good fit for them" (Personal Communication).

Dr. J.'s views about constructivism mirror his pedagogy. He believed that the students were actively seeking meaning based on their naïve notions. Therefore, he emphasized the importance of assessing students' prior knowledge. As observed above, he used several methods, including brainstorming and constructing concept maps, in order to determine prior knowledge and identify misconceptions. The use of these methods was evidence of one aspect of Dr. J.'s belief in constructivism.

Next, he believed that students should come to realize that they are basically responsible for their science learning. He mentioned that "The more they gather information for themselves and find out for themselves, the more meaningful their learning will be" (Personal Communication). Therefore, he was not totally dependent upon a lecture, a textbook, or cookbook laboratories. He used a variety of strategies in order to provide the best science learning to help his students develop their understanding of science. Cooperative learning techniques (e.g., jigsaw approach, group classroom activities) as well as real world, hands-on learning were primarily used in his classroom.

As Fortner (2002) stated, "grouping lessons not only helps students see the relationships between experiences but also assists in getting a wider array of information put before the students for real use" (p. 86). Students also agreed that collaborative learning in their class helps them learn science. In addition, several studies found that hands-on activities helped students 1) to achieve understanding about science and the environment, 2) to experience concepts and processes of the real world, and 3) to apply the principles to real world settings (LaPorte and Sanders, 1993; Wolfinger, 1994). Dr. J.'s middle school had adopted constructivist-based ideas and the ESE framework in terms of student-centered learning where the teacher was more of a facilitator than a director.

Finally, Dr. J. used a variety of assessment strategies. He used open-ended evaluations that allowed students to respond in several ways. Assessment in groups is done at times in the forms of group presentations. He also used oral presentations throughout students' mini-projects and/or group projects as an assessment method. His rubrics and concept mapping were often used to keep students 
accountable. His instructional strategies were very compatible with ESE-based (constructivist-based) teaching and learning strategies and pedagogy.

\section{Realities of Implementing Earth Systems Education}

\section{Advantages (or Benefits) of the ESE-based Science Curriculum}

When I asked Dr. J. about student benefits (or advantages) from his ESE based curriculum, he first responded that the most notable benefit of the curriculum was that students had opportunities to connect their science learning to the real world and to their daily life experiences. In addition, he stressed the flexibility of the curriculum that promoted the use of a variety of teaching strategies, activities, and topics for students.

This is an advantage because we have the flexibility to choose activities from many different sources and to design our own. Many of these have a local focus. We also take students on two field trips a year to get them out into the ecosystems to study them. We often select topics that involve the interaction of one or more of Earths subsystems. A perfect example of this is global climate change. It is a very complex interaction of air, land, and water and has been influenced by human activity. A modern day example we study that includes many things included in climate models is ENSO. By having some understanding of how ENSO works, students can get some insight into how climate might change. (Written Question)

As he stated in response to the written question, one of the key benefits in ESE is group collaboration for learning science. Through group projects, students can experience learning together, share information, and present their group work.

Dr. J.: They get to learn science as they experience it in the real world, as much as possible. The flexibility of the curriculum allows teachers to give students a "say" in what they learn (inquiry). Students experience a variety of teaching strategies and can use their own strengths to learn. They also work with other students from time to time in group activities. The social negotiation that occurs in groups reinforces learning.

When I observed his class, he mentioned to his students "I don't want you to see science as a foreign language, simply memorizing a lot of words." Dr. J. wants science to be more meaningful and reasonable, and wants students to learn things to take with them through their life rather than something to memorize for a test (Observation). The most important benefit Dr. J. thought is that the ESE curriculum can make science fun and enjoyable, helping students become happy learners.

\section{Barriers (or Difficulties) of Teaching ESE}

With regard to Dr. J.'s views on any difficulties of Earth system approach for teachers, he expressed two difficulties of teaching ESE: lack of a variety of teaching materials and teaching without a textbook.

Written Question: What do you perceive to be some of the barriers or difficulties in teaching with an Earth system approach?

Dr. J.: It was a challenge at first to find a variety of teaching materials. We found several activities from many sources, including many things developed at Ohio State and have developed the rest ourselves. The school district has been very open about us developing and implementing our curriculum. A few parents have suggested that our curriculum lacks rigor. There have been, maybe, three parents in 10 years who have said so. We do not use a textbook so I emphasize to the students that their notebook is their textbook and they should do a good job writing it. I think this gives the students some control over what they do. We have had some concern from parents about not having a textbook because they may have a hard time helping their child with homework and the homework assignments dont look as well defined as an assignment with page numbers out of a textbook.

With regard to the textbook, he mentioned that not using a textbook could make new science teachers uncomfortable with teaching ESE. He said, "I suppose if I was a new teacher with no teaching experience and maybe didn't feel comfortable with a broad range 
of background knowledge, that's when a textbook would be nice" (Interview). Since the curriculum includes multi-disciplinary sciences of global change and other environmental issues, a new teacher may not teach ESE well if he or she does not have a strong base of Earth systems science content knowledge.

When I joined the class on a field trip to Big Darby Metro Park, Dr. J. expressed that one barrier for ESE could be caused by the lack of enough time to be outside and discuss subjects first hand, instead of doing most of the discussions and instruction in a classroom environment. Therefore, he said, field trips are required in ESE to show students how unique Earth is because environmental components are mostly included in the domains of ESE (Personal Communication).

\section{Interpretations}

As stated above, Dr. J. described several notable benefits of the ESE curriculum in the middle school. Based on the data from observations and interviews, one of the things I saw as an important benefit was that the curriculum gave students many more natural ways than conventional programs to make connections to the real world. Even though he mentioned that time-limitations for field experiences could be one barrier, he did help students make explicit connections between their science learning and the real world application during activities in the classroom. It would appear that his students had good opportunities to apply their science learning and knowledge to the real world or their immediate world (e.g., weather and environmental issues in their local community).

With regard to his teaching materials, some parents were not pleased because he did not use many traditional teaching methods and textbook-based lessons. Through observations, I found that his teaching materials were composed of a variety of hands-on activities rather than a textbook. I noticed that a lack of published materials and having no textbook were not challenges for the students. The students seemed to think that they have more benefits to learning science without a textbook.

Harold: I enjoy science class because we dont use a textbook. I like this method of learning because science changes everyday and textbooks would be out dated. I also like how we usually do experiments relating to every topic because I have a visual perception of how the topic works or happens. I think the reason I like science is very interesting and we learn it in more of a hands on way instead of just reading it out of books, like we do in other classes.

Heidi: I like it [science] because we dont have to carry a textbook around with us all the time, and our teacher [Dr. J.] makes learning science so much fun. I also like when we do experiments.

Kathy: I like the way Dr. J. teaches science and it is an easy subject for me to understand. I dont like learning from a textbook. I like doing things hands on.

Janet: My science teacher, Dr. J., is a very good teacher. He explains the topics we learn about thoroughly, so we can have a more clear understanding. Worksheets are much better than textbooks because we get to explore. Students usually tend not to read the textbook!

The ESE curriculum materials and Dr. J.'s instructional activities helped students learn real world-based science. I also identified having no textbook as one of the notable characteristics of the ESE curriculum provided by Dr. J.

Confirming one of the difficulties of teaching ESE as expressed by Dr. J. was an interview with Dick. He pointed out that longer period field trips could be better to experience and do an activity.

Researcher: What will you remember most about learning outside of school?

Dick: Probably Tar Hollow. Um, we were there for a longer time, you can experience, see more things there... If you go on a fieldtrip for a day it sort of seems like youre being rushed to accomplish everything you know on your agenda. But when youre there for a longer period of time, its not as rushed. And in the activity where we compared all the fieldtrips and listed various species from each one we had found and Tar 
Hollow had by far the most species we had found because wed been there longer. But being there longer and seeing more species meant that we learned more.

While I observed the field trip for one-day, the students seemed to need more time to complete their activities and tasks.

\section{Summary and Implications}

In order to document descriptive and analytical accounts of ESE curriculum and instruction in a natural classroom, I studied the science classrooms of an information-rich teacher who had experience with implementing ESE in a middle school and who employed the ESE conceptual focus and approach in his science curriculum. He developed a two-year Earth Systems Education (ESE) course that was substituted for the traditional seventh grade life science and eighth grade Earth science courses at his school. In this investigation, I conducted a case study of the ESE curriculum provided by Dr. J.. My research questions primarily focused on the teacher's views of ESE, its theoretical background, and several characteristics of ESE curriculum and instruction.

\section{Dr. J.'s Views about ESE Experiences}

Dr. J.'s views about ESE and his ESE curriculum and instruction were first examined through interviews and observations. As the evidence was analyzed, it became apparent that there are commonalities between constructivist theory and his perceptions of science education and pedagogy. He holds a constructivistbased philosophy for teaching ESE. He believes that science learning is an active process by the students, facilitated by the teacher. Students are actively constructing new knowledge based on their prior experience, including misconceptions. Therefore, he strongly believes that teachers should know their students' pre-existing knowledge, beliefs, and misconceptions. He uses several teaching strategies to identify students' misconceptions (e.g., concept mapping, brainstorming, open-ended questions). In addition, he uses a variety of teaching strategies, all of which are compatible with ESE and constructivist theory. His major strategies include cooperative learning, inquiry, a jigsaw approach, labs, authentic activities, field trips, and project-based learning. In particular, his use of concept maps, cooperative learning, and authentic activities are primarily based on constructivist learning theory and meaningful learning (Ausubel, 1963; Novak, 1990, 1991; Piaget 1977).

Next, he believes that middle school students need more opportunities to make sense of the world around them. Therefore, he explains that his ESE curriculum and instruction focuses on making science learning relevant to student real world experiences and real life environments. Providing authentic classroom activities and field trips is also consistent with the constructivist perspective. He also provides integrated hands-on activities rather than "cookbook" labs because he wants to provide students with more opportunities to use their thinking and process skills.

With respect to his views about benefits and difficulties associated with ESE, he suggests that the most important benefit is that the curriculum provides authentic-based, hands-on activities and makes connections between students and everyday life experiences. In addition, he believes that it is not difficult to teach using ESE. However, the lack of time devoted to field trips and a lack of suitable resource materials that reflect ESE are obstacles to the implementation of the curriculum for some teachers.

\section{Characteristics of the ESE Curriculum}

There are several notable characteristics of the ESE curriculum. First, the curriculum, developed by Dr. J. and other teachers in the middle school, was based on a framework of Earth Systems Education. As Mayer (1995) suggests, the Earth as a system provides conceptual focus and themes for organizing the ESE curriculum. For example, the focus for Dr. J.'s eighth graders begins with local issues and topics around their community and Ohio and extends to global issues, such as global warming, El Niño, and ozone depletion. The topics for Dr. J.'s curriculum were 
selected on the basis of the ESE framework. The instructional subject matter is primarily composed of interdisciplinary investigations, human interactions (or influence) with Earth systems, the Framework of Earth Systems Understandings, and global concepts approached on a regional basis.

Second, evidence was obtained during the study that emphasized the importance of hands-on activities. Since hands-on learning is supported by Dewey (1916, 1938) as a vital part of the education of all students, the concept of teaching through hands-on learning methods has continued to be an important part of science education (Folkomer, 1981, LaPorte and Sanders, 1993; Orion and Hofstein, 1994; Tal, 2001; Thomson and Hartog, 1993; Wolfinger, 1994). Dr. J.'s students responded that hands-on based experiences and activities during the field trips helped them to understand the local environment and nature. Students perceived themselves better able to understand the concepts presented in the lessons by hands-on learning.

Third, field trips play an important role in ESE, fostering greater understanding of the local environment and human influences on it. The curriculum included several valuable field trips for both seventh and eighth graders. The major focus of the field trips was examining and experiencing the local environment, human influences on the environment, and science knowledge and concepts. In addition, evidence from the students indicates that they were able to better understand the concepts through the field trip experiences. It seems particularly significant that many of the students mentioned the field trips as most interesting and enjoyable learning activities. According to the survey, the students responded positively to the field trips as a part of their curriculum, and showed interest in learning during the field trips.

The final notable characteristic of the curriculum is the inclusion of mini-projects organized by Dr. J. Twice a year, the students study any science topic of their choice and develop an oral presentation (miniproject) on a topic. The responses of students to their mini-projects indicated that they had an opportunity to study new and interesting science topics in depth and to learn about science process skills (e.g., observing, inferring, and organizing and interpreting data) and other skills (e.g., presentation skills, information searching skills on the Internet). The mini-projects also helped students to understand additional Earth system and science concepts. On the oral presentation day, students could share their topics with other students. The teacher videotaped and assessed presentations using a teacher-made evaluation form and provided productive feedback and comments.

\section{Implications}

Several findings in this study have implications for future research. First, while ESE has continued to evolve since the first year, 1989, little empirical research has been gathered to evaluate the ESE curriculum in practice. More qualitative and quantitative research should be conducted regarding the effectiveness of Earth systems-based curriculum and instruction. In addition, from the evidence in this study, hands-on and project-based learning and field trips as a part of the curriculum could benefit students' learning and understanding. More researchbased information and evidence needs to be gathered regarding the effectiveness of hands-on learning and project-based learning on students' science achievement and attitudes. Regarding field trips, longitudinal research should be conducted on the relationships between field trips and students' cognitive and affective learning outcomes.

Second, ESE curriculum and instruction may have a positive effect on student achievement. However, there has been very limited research with respect to the effects of ESE curriculum and instruction on student achievement and performance. In addition, what is the community perception about the effectiveness of the ESE-based program compared to more traditional science curriculum? And is this perception different than students' perception of the ESE-based program? It would be of interest to conduct a comparison study by using a standardized test to evaluate students' science achievement in an ESE classroom compared 
to a non-ESE classroom.

Third, the duplication of this study in other schools, which are employing Earth systems-based curriculum for teaching students, would help to confirm the evidence found in this case study. Also, a replication of this study could reveal more or different evidence related to different populations and different settings.

Finally, this research was one of the qualitative case studies to focus on ESE curriculum and one exemplary teacher. This research experience and findings can be helpful in developing a basic understanding and framework for integrated science curriculum in Korea and provide a conceptual focus of teaching earth science in Korea.

\section{References}

Ausubel, D.P., 1963, Cognitive structure and the facilitation of meaningful verbal learning. Journal of Teacher Education, 14, 217-222.

Ben-zvi-Assaraf, O. and Orion, N., 2005a, A study of junior high students' perceptions of the water cycle. Journal of Geoscience Education, 53, 366-373.

Ben-zvi-Assaraf, O. and Orion, N., 2005b, Development of system thinking skills in the context of Earth System Education. Journal of Research in Science Teaching, 42, 518-560.

Biological Science Curriculum Study, 2000, Making sense of integrated science: A guide for high schools. BSCS, Colorado Springs, USA, $243 \mathrm{p}$.

Cho, K. and Kang, H., 2002, Reaction of students for the field application of ESE program: Focusing on the global climate game. Journal of Korean Earth Science Society, 23, 299-308.

Cho, K., Lee, G., Jang, J., and Kang, H., 2006, Application and student responses for ESE program in the $10^{\text {th }}$ grade classroom: Focusing on volcanic eruptions and global climate change. Journal of Korean Earth Science Society, 27, 251-259.

Corbin, J.M. and Strauss, A.L., 2008, Basics of qualitative research: Techniques and procedures for developing grounded theory. Sage, Newbury Park, CA, USA, $379 \mathrm{p}$.

Dewey, J., 1916, Democracy and education. Macmillan, NY, USA, $290 \mathrm{p}$.

Dewey, J., 1938, Experience and education. Collier, NY, USA, $116 \mathrm{p}$.

Dori, Y.J., and Tal, R.T., 2000, Industry-environment projects: Formal and informal science activities in a community school. Science Education, 84, 95-113.

Folkomer, T., 1981, Comparison of three methods of teaching geology in junior high school. Journal of Geological Education, 29, 74-75.

Fortner, R.W., 2002, Cooperative learning: A basic instructional methodology for GSL. In Mayer, V.J. (ed.), Global science literacy. Kluwer Academic Publishers, Dordrecht, Netherlands, 79-92.

Goldman, S.R., 1997, Learning from text: Reflections on the past and suggestions for the future. Discourse Processes, 23, 357-398.

Hlawatsch, S., Bayrhuber, H., Euler, M., Hansen, K.H., Hildebrandt, K., Hoffmann, L., Lucius, E.R., Siemer, F., and Hassenpflug, W., 2003, Earth System Education in Germany. In Mayer, V.J. (ed.), Implementing global science literacy. The Ohio State University, Columbus, OH, USA, 155-156.

Jax, D.W., 1995, A case study of the initiation and implementation of an innovative integrated science curriculum for grades nine and ten. Unpublished Ph.D. dissertation, The Ohio State University, Columbus, OH, USA, $340 \mathrm{p}$.

Kali, Y., Orion, N., and Eylon, B-S., 2003, Effect of knowledge integration activities on students' perception of the Earth's crust as a cyclic system. Journal of Research in Science Teaching, 40, 545-56.

Kim, C-J. and Kwak, Y. (eds.), 2004, Seoul conference for International Earth Science Olympiad (IESO) Conference Proceedings. Seoul National University, Korea, $158 \mathrm{p}$.

Kim, Y.J. and Jeong, J.W., 2009, Understandings on the cycle as a substance and ESE. Journal of the Korean Association for Research in Science Education, 29, 951962.

Kim, Y.J., Jeong, J.W., and Wee, S.M., 2009, Analysis of conceptions of earth system cycles as perceived by college students. Journal of the Korean Association for Research in Science Education, 29, 963-977.

Krajcik, J., Blumenfeld, P.C., Marx, R.W., Bass, K.M., and Fredricks, J., 1998, Inquiry in project-based science classrooms: Initial attempts by middle school students. Journal of the Learning Sciences, 7, 313-350.

Lang, M., 2002, The Earth as system: A topic for integrated science education. Paper presented at the annual meeting of the National Association for Research in Science Teaching, New Orleans, LA, p. 173.

LaPorte, J.E. and Sanders, M., 1993, Integrating technology, science, and mathematics in the middle school. The Technology Teacher, 52, 17-21.

Lee, H. and Fortner, R.W., 2005, International geosciences educators' perceptions of approaches to K-12 science education for the $21^{\text {st }}$ century. Journal of Geoscience Education, 53, 198-203. 
Lee, H. and Kim, S., 2009, The recognition characteristics of science gifted students on the earth system based on their thinking style. Journal of Science Education, 33, 12-30.

Lee, H. and Kwon, Y., 2008, Development and application of earth science module based on earth system. Journal of Korean Earth Science Society, 29, 175-188.

Lee, H., Fortner, R.W., and Mayer, V.J., 2004, Earth systems education: An integrated science curriculum construct for Korea. The Secondary Education Research, $52,397-426$.

Lee, J., Maeng, S., and Kim, C., 2007, Science teacher's perceptions and orientations about earth systems education: A case study. Journal of Korean Earth Science Society, 28, 705-717.

Lim, E., Hong, S., and Jeong, J., 2000, Field application of Earth Systems Education. Journal of Korean Earth Science Society, 21, 93-102.

Mayer, V.J. (ed.), 2002, Global science literacy, Kluwer Academic Publishers, Netherlands, $242 \mathrm{p}$.

Mayer, V.J. (ed.), 2002, Global science literacy. Kluwer Academic Publisher, Netherlands, $242 \mathrm{p}$.

Mayer, V.J. (ed.), 2003, Implementing Global science literacy. Earth Systems Education Program, The Ohio State University, Columbus, OH, USA, 293 p.

Mayer, V.J., 1991, Framework for Earth systems education. Science Activities, 28, 8-9.

Mayer, V.J., 1995, Using the earth system for integrating the science curriculum. Science Education, 79, 375-391.

Mayer, V.J., 1996, Science literacy in a global ear. In KARSE. (ed.), Science education for $21^{\text {st }}$ century. The $20^{\text {th }}$ Anniversary of KARSE International Seminar and Workshop in Science Education, Korea, 13-41.

Mayer, V.J., 1997, Science literacy in a global era. Hyogo University of Teacher Education Journal, 17, 75-89.

Mayer, V.J. and Fortner, R.W. (eds.), 1995, Science is a study of Earth: A resource guide for science curriculum restructure. The Ohio State University, OH, USA, $246 \mathrm{p}$.

Mayer, V.J. and Tokuyama, A., 2002, Evolution of global science literacy as a curriculum construct. In Mayer, V.J. (ed.), Global science literacy. Kluwer Academic Publishers, Netherlands, 3-24.

Merino, B.J. and Hammond, L., 1998, Family gardens and solar ovens: Making science education accessible to culturally and linguistically diverse students. Multicultural Education, 5, 34-37.

Merriam, S.B., 1988, Case study research in education. Jossey-Bass Publishers, CA, USA, $304 \mathrm{p}$.

Merriam, S.B., 2009, Qualitative research: A guide to design and implementation. Jossey-Bass Publishers, CA, USA, $320 \mathrm{p}$.

Miles, M.B. and Huberman, A.M., 1994, Qualitative data analysis. Sage, Thousand Oaks, CA, USA, 256 p.

Ministry of Education and Human Resources Development [MOE], 2000, High school science curriculum, MOE, Seoul, Korea, 243 p.

Ministry of Education, Science and Technology [MEST], 2009, Revised national science curriculum, MEST, Seoul, Korea, 63 p.

Moje, E.B, Collazo, T., Carrillo, R., and Marx, R.W., 2001, "Maestro, What is 'Quality'?": Language, literacy, and discourse in project-based science. Journal of Research in Science Teaching, 38, 469-498.

National Research Council, 1996, National science education standards. National Academy Press, Washington, DC, USA, $272 \mathrm{p}$.

Novak, J.D., 1990, Concept mapping: A useful tool for science education. Journal of Research in Science Teaching, 27, 937-949.

Novak, J.D., 1991, Clarify with concept maps: A tool for students and teacher alike. The Science Teacher, 58, 4549.

Oh, H. and Kim, C., 2010, An analysis of earth system understandings (ESU) of $8^{\text {th }}$-grade students' imagery about the earth represented by words and drawings. Journal of Korean Earth Science Society, 31, 71-87.

Oh, H., Kim, J., Yu, E., and Kim, C., 2009, An analysis of students' cognitive characteristics through a drawing activity in teaching module of the earth systems education. Journal of Korean Earth Science Society, 30, 96110.

Orion, N. and Hofstein, A., 1994, Factors that influence learning during a scientific field trip in a natural environment. Journal of Research in Science Teaching, 31, 1097-1119.

Park, D., 2001, A Study of Earth System Science in the Community (EarthComm) in Terms of Its Congruency with the Visions in the National Science Education Standards and Its Effectiveness in Improving Student Learning. Unpublished Ph.D. dissertation, University of Iowa, Iowa City, Iowa, USA, $154 \mathrm{p}$.

Park, D., 2006, Curriculum reform movement of science education in the US: A case of earth science curriculum. Journal of Korean Earth Science Society, 27, 730744.

Patton, M.Q., 1990, Qualitative evaluation and research methods. Sage, Newbury Park, CA, USA, 688 p.

Piaget, J., 1977, The development of thought: Equilibrium of cognitive structures. Viking, NY, USA, $433 \mathrm{p}$.

Rudmann, C.L., 1994, A review of the use and implementation of science field trips. School Science and Mathematics, 94, 138-141.

Shin, D., 2001, Earth science in the perspectives of environmental education. Journal of Korean Earth Science Society, 22, 147-158. 
Shin, D., Lee, Y., Lee, K., Lee, E., and Lee, K., 2005, Proposcurriculum of the future-oriented earth science education placing on the earth environment. Journal of the Korean Association for Research in Science Education, 25, 239-259.

Tal, R.T., 2001, Incorporating field trips as science learning environment enrichment: An interpretive study. Learning Environments Research, 4, 25-49.

Wolfinger, D.M., 1994, Science and mathematics in earlychildhood education: Curriculum and teaching. Harper
Collins College Publishers, NY, USA, 295 p.

Yu, E., Lee, S., and Kim, C., 2007, Investigating sciencetalented students' understandings and meaning generation about the earth systems based on their geological field trip reports. Journal of Korean Earth Science Society, 28, 671-683.

Yu, E., Oh, H., and Kim, C., 2008, The influence of global science literacy-oriented instruction on students' views of the nature of science. Journal of Korean Earth Science Society, 29, 602-616.

Manuscript received: July 29, 2010

Revised manuscript received: August 27, 2010

Manuscript accepted: September 10, 2010 